This item was submitted to Loughborough's Research Repository by the author.

Items in Figshare are protected by copyright, with all rights reserved, unless otherwise indicated.

\title{
Public libraries, museums and physical convergence: Context, issues, opportunities: A literature review Part 1
}

PLEASE CITE THE PUBLISHED VERSION

https://doi.org/10.1177/0961000618769720

\section{PUBLISHER}

(c) The Authors. Published by Sage

\section{VERSION}

AM (Accepted Manuscript)

\section{PUBLISHER STATEMENT}

This work is made available according to the conditions of the Creative Commons Attribution-NonCommercialNoDerivatives 4.0 International (CC BY-NC-ND 4.0) licence. Full details of this licence are available at: https://creativecommons.org/licenses/by-nc-nd/4.0/

\section{LICENCE}

CC BY-NC-ND 4.0

\section{REPOSITORY RECORD}

Warren, Emily, and Graham Matthews. 2019. "Public Libraries, Museums and Physical Convergence: Context, Issues, Opportunities: A Literature Review Part 1”. figshare. https://hdl.handle.net/2134/33369. 


\title{
Public libraries, museums and physical convergence. Context, issues, opportunities: a literature review. Part 1.
}

\author{
Abstract \\ There has recently been a growth in physical convergence in cultural heritage \\ domains. Part 1 examines this 'trend', its drivers and related issues, with \\ particular focus on public libraries and museums. It offers an overview of \\ practice, challenges and opportunities. Through thematic analysis of a \\ comprehensive, literature review of both domains that looked at the wider \\ aspects of collaboration, cooperation, partnerships and integration in the sector \\ as well as physical convergence, it provides insight into background, theory and \\ activities worldwide. It presents discussion on the meaning of convergence, the \\ concept of 'memory institutions', the relationship between public libraries and \\ museums in the context of convergence, shared mission and values, \\ convergence and re-convergence, and professionalism and divergence. It \\ concludes with consideration of practical aspects such as motivations for \\ convergence, including digital technology, changing user expectations and
}


culture, and economic and political challenges that impact on physical convergence in a dynamic local government environment.

\section{Keywords}

Libraries. Museums, Archives, Convergence, Collaboration. Co-location, Physical convergence. LAMs.

\section{Introduction}

This two-part article presents a review of developments and issues relating to physical convergence (sometimes referred to as co-location) between public libraries and museums (in public ownership), the challenges it raises, conceptual and practical, and the opportunities it affords. It draws on analysis of a review of the literature of both domains undertaken to inform the development of a case study of a physically converged library and museum in the UK (a rare example of a UK public library and museum that share an integrated space). Whilst the focus of the case study was on physical library and museum convergence in the UK local authority context, the literature review on which this paper is based was broader in scope so that the case might be considered in the wider convergence context - reflecting other forms of 'convergence' - 
cooperation, collaboration, partnership and integration between libraries and museums of different types, all of which may have relevance for physical convergence. It is intended that this may be of interest and use to those planning for physical convergence, or co-location, by offering an overview of the issues and opportunities physical convergence might bring, from a library and museum perspective, and setting this in the wider context. (One of the authors has worked in a physically converged library and museum service in the UK and experienced first-hand the complex issues associated with such co-location.) Convergence has been the subject of international interest for several decades. More recently, physical convergence has been viewed as an innovative answer to the increasing challenges and demands faced by cultural heritage institutions, particularly within local government. There is, to date, little published empirical evidence from original research or analysis of best practice to underpin and inform policy and practice relating to physical convergence of libraries and museums. The two-part article identifies and analyses such research that has been published and first-hand accounts of convergence, and presents this in a thematic arrangement; it also reflects on appropriate theoretical considerations of the broader aspects of the subject. 
Whilst the focus of the article is on public libraries and museums, relevant literature concerning, for example, collaboration involving other types of these, and examples of other cultural institutions, such as archives and galleries, and initiatives arising from digital convergence, has also been consulted and included. Likewise, whilst public libraries and museums were the key emphasis of the review, in order to gain an in-depth understanding of convergence, literature relating to collaboration between non-local authority organisations was also considered where relevant.

The article overall examines the convergence trend, its drivers and related issues, with a view to providing contextual background for those involved in planning and developing physical convergence. It offers insight into relevant theory as it considers various viewpoints on convergence and provides a synthesis of different attitudes. It does this with an international perspective, with worldwide examples. It thus pulls together international thinking and practice on library and museum convergence over a period when such developments have considerable significance for those working in public libraries and museums, those who use them, and policy makers and administrators at local and national level. It is intended that this broad approach and coverage, which has resulted in a novel state of the art review, will provide 
an essential point of reference for those involved in initiating and developing physical convergence in libraries and museums, particularly for library and museum managers in the UK, as it draws on sources relating to both museums and libraries. It thus raises awareness among library managers of museum managers' perspectives on the topic, and vice versa. It is intended that they will use their judgement to determine what might be relevant or transferrable with regard to their organisational circumstances in the increasingly complex and changing local government environment.

The article is presented in two parts. Part 1 provides an introduction to the topic - it introduces theoretical aspects related to this - what is convergence, its different forms, how does it relate to collaboration, cooperation, partnership? What is behind the recent trend for physical convergence? It considers international perspectives on this. It moves on to consider the relationship between libraries and museums, their role as 'memory institutions', shared missions and values, whether recent 'shared' activities are convergence or reconvergence, and, what of those working in these institutions - how does convergence, and physical convergence, lie with professionalism and divergence? This Part 1 ends with consideration of motivations for convergence 
in the broader sense: digital technology, culture and changes in users and their expectations, and economic and political challenges.

Part 2 moves on to consider barriers to convergence in general, but relevant to physical convergence, and risks associated with its implementation: such as institutional differences, ethical challenges, organisational culture and resistance, and operational and strategic complexity. Following this, factors for successful convergence: vision, strategy and planning, communication and trust, leadership and management, professional education, training and development, are addressed. It continues with an overview of the potential benefits of convergence, both general and physical, improved cultural offer and visibility, financial savings and cross-sector learning. The conclusion at the end of this part relates to both parts and highlights different international circumstances, and the growing questioning of the 'convergence narrative'.

\section{Libraries and museums - governance, funding and management}

It is appropriate before addressing convergence to consider briefly the range of types of libraries and museums and their varied governance, funding and management, which, along with other factors, internal and external, will 
influence the kind and level of convergence in which they can participate. Readers will note this in the examples and views expressed from academics and practitioners around the world. They will also take from this, that irrespective of national, regional or local circumstances, library and museum managers in different types of organisations face similar issues and opportunities with convergence in its different forms. There may be experiences and lessons from which they can learn, practice they can transfer or amend to their situation, but they should note the original purpose of such convergence and the environment from which it emanated. A key current factor faced by many, for example, is financial constraint, and this has given rise to innovative ways, often working with others, to generate income. Professional associations can be a useful source of information on the specifics of governance and funding, for example, and, in the wider domain and sector context (see, for example, Babbidge 2013, Chartered Institute of Library and Information Professionals, 2017, and Museums Association 2017).

Drawing on a range of sources, Loach et al. provide an overview of the museum and library sector in the UK. They inform that 'there are around 2500 museums in the UK. These range from national museums run by central government, whose collections are considered to be of national importance; to local authority 
run museums that hold collections which tend to 'reflect local history and heritage', to 'a diverse range of independent museums owned by registered charities and other independent bodies or trusts' (Museums Association, 2015 in Loach et al., 2016: p.187). They advise that the UK has 'an estimated 4145 public libraries' (Public Libraries News, 2015a in Loach et al., 2016: p.187) and that 'these libraries are generally run by local authorities' (GOV.UK, 2013 in Loach et al., 2016: p.187) and, 'as with museums, exist alongside a variety of other kinds of library' (Loach et al., 2016: p.187), examples of which include: national, academic, and special libraries, which Loach et al. note are 'often privately owned' (2016: p.187). They add: "This list is by no means exhaustive. There are numerous other types of library and museum, and the ways in which they are classified can also often be far more complex than suggested, owing to systems of governance that can sometimes cross between public, private and academic sectors" (Loach et al., 2016: p:187).

McCall, too, refers to complexity in the museum domain in the UK: "There are also many different types of museums (trust, independent, national, local authority, regimental) that have different governance and funding structures" (2016: p.99), and she also refers to fragmentation - administrative, managerial and geographical. 
Groninger (2016) comments:

Rhetoric defining UK museums categorizes them by governance type, delineating differences in funding, management, and oversight. The fiftyfour National museums, established within a national policy agenda, are funded by the four countries' central government departments, are exempted charities with boards of trustees, and are accountable not merely to stakeholders, but also report to the National Audit Offices (NAO) ... Local Authority museums, the most common kind of UK museums, are diverse in size and type, yet all are public service departments primarily funded, administered, and governed directly by local council museum services. ... Independent museums include diverse types of organizations like charities and volunteer-run museums. These museums can apply for government-sponsored grants, but receive most income through admission fees, corporate ventures like a museum café, or from individual, corporate, or foundation giving. (Groninger, 2016).

With regard to funding and governance, Paroissien (2006) provides interesting, 
still relevant examples of "the diversity of models of museum governance and funding affecting museums throughout the world and even within a single country" (2006: p.2) ... And, depends on "each individual museum in the context of the societies to which they belong" (2006: p.3)... "In recent years, museums traditionally funded wholly or partly by government have been endeavouring (or forced by changing government policies) to raise increasing proportions of their resources from both their own commercial activities and support from the private sector." (2006: p.3).

Lindqvist expands on this:

The financial management of museums is complex. The oversight of the operation is affected by numerous objectives and schedule constraints, as well as by revenue streams that do not follow for-profit revenue models. In addition to these complex internal factors, there are complex external factors in the museum sector at work as well. These include the increased competition for funding due to the increase in the number of museums; a decrease in the public subsidy for heritage projects; changing political priorities, and the ongoing interest of donors and politicians in supporting the establishment of new museums rather than underwriting standard museum maintenance. 
(Lindqvist, 2012: p.10-11)

These examples illustrate the complexities regarding managing, funding and governance of libraries and museums (public and other) - these will vary from country to country as indicated in this quote from the US website ilovelibraries, an initiative of the American Library Association:

Today there are more than 16,000 public libraries in the United States. They are usually funded by public funds, administered at the state, county and local levels. Cities often provide their own public libraries. In some states, county libraries serve the populations of unincorporated areas of the county, not covered by city library service. In some instances, when a city is not able to provide library service, it may contract with the county to serve its residents. State libraries often serve as repositories for public information but also serve their state legislatures as a research arm of state government. In the 50 states, there probably aren't 50 unique ways of administering library service, but there certainly are many different organizing principles at work.

(ilovelibraries, 2017) 


\title{
The Convergence Trend
}

Convergence has been the subject of international interest for several decades;

Tanackovic and Badurina trace the theoretical origins of this curiosity back to the 1930s:

\begin{abstract}
Available literature shows that theoretical thought about the integration and separation of LAMs emerged in the 1930s in the USA, and shortly after in Europe. Archivists and librarians (and later on curators) started thinking about the similarities and differences in their working experiences and discussed possible areas of collaboration
\end{abstract} (Tanackovic \& Badurina, 2009: p.229)

Convergence has been viewed as an innovative answer to the increasing challenges and demands faced by cultural heritage institutions, particularly within local government: "in recent years, a number of local authorities have brought archives, museums and a variety of other services together to form broad leisure, heritage and cultural directorates" (Jones, 1997: p.27). The interest in this type of integrated working between cultural heritage institutions is 
reflected in the varied number of ways it is referred to throughout the literature, including LAM (libraries, archives and museums), GLAM (galleries, libraries, archives, museums) and ALM (archives, libraries and museums) convergence. Marcum comments that "our era in cultural agency history will go down as one of exceptional collaborative enthusiasm" (2014: p. 76) which is evidenced in the literature over the past fifteen years. More recently, this has started to include examples of physical convergence, or co-location of libraries and museums.

In order to understand this trend better, it is first appropriate to consider what convergence, in theory and in practice, can mean in the context of libraries and museums.

\section{What is Convergence?}

Collaboration and convergence are terms often used interchangeably / imprecisely throughout the literature to describe relationships between cultural organisations, including libraries and museums. To these, can be added cooperation, partnership, and integration. While some research attempts to distinguish between collaboration and convergence, the use of these terms 
remains inconsistent throughout the literature. This influenced the rationale for our literature review (covering that of libraries and museums), which was to identify sources that focused on physical convergence (for example, co-location and /or joint use or integrated facilities), and to include also those that addressed broader 'convergence, but with content of relevance to the planning, management, and development of physical convergence.

Evans cynically describes collaboration as "an unnatural act, practised by nonconsenting adults" (2002: cited in Martin, 2003), whilst Soehner likens collaboration to a "transformational change that is akin to letting go of one trapeze in mid air before a new one swings into view" (2005: p.10). In 2003 Diamant-Cohen and Sherman predicted that collaboration between libraries and museums would be a growing trend and declared, "library and museum collaborations are the wave of the future" (p.102). Diamant-Cohen and Sherman describe collaboration in broad terms as a phenomenon that can drastically range in scale: "there are many possible ways to collaborate, from small, one-time projects to large long-term projects that can drastically change the way people think about these institutions" (2003: p.102). Gibson et al. echo this point by describing library and museum collaboration as taking many forms: 
Library-museum collaboration can be defined as the cooperation between a library and a museum, possibly involving other partners. These partners may collaborate in one-off projects or a continuous programme of events and they may be co-located or they may be located away from each other (2007: p.53)

While several commentators describe their personal understanding of convergence, Zorich et al.'s 2008 model The Collaboration Continuum and Yarrow et al.'s 2008 IFLA report provide a more rigorous examination of the meaning of collaboration and convergence.

In their seminal OCLC publication Beyond the Silos of the LAMs, Zorich et al. highlight the importance of properly defining these terms and comment that collaboration has "become an over-arching rubric, covering everything from simple interactions...to highly intricate LAM activity" (2008: p.10). Between 2007 and 2008, Zorich et al. conducted a series of workshops in order to explore LAM collaboration and support institutions to work together in providing common services (2008: p.8). The outcome of these workshops is their definition of the five stages of the LAM Collaboration Continuum: from, "contact, 
when groups first meet to open up a dialogue and explore commonalities in activities and needs" (2008: p.10), to cooperation, "an activity or effort that offers a small, yet tangible, benefit" (2008: p.11) and then on to coordination where "a framework is required to organise efforts" (2008: p.11). Zorich et al note that: "Cooperation and coordination rely on informal or formal agreements between groups to achieve a common end. The next point on the continuum, collaboration, moves beyond agreements". In this stage, "Information is not just exchanged; it is used to create something new" (2008: p.11). The final stage, convergence, "is more ambitious than cooperation and coordination and much harder to develop and sustain." (2008: p.12). They also state that as participants move through the five stages of this continuum the investment, risk and rewards all increase proportionately (2008: p.10). This is reflected in Waibel and Erway's Collaboration Quadrant (2009: p.328); for which they define investment as "the amount of time, resources, trust, and compromise necessary for a collaboration" and rewards as "the long-term, transformative and liberating impact of the collaboration" (2009: pp.328-329). Although the Collaboration Continuum and the Collaboration Quadrant are based on research carried out with libraries, archives and museums from a predominantly academic setting, it can be argued that the five stages of collaboration by Zorich et al. are transferable to other contexts, including public libraries and museums. 
While Zorich et al. sought to define a scale of investment and reward, the three broad areas of collaborative activity presented by Yarrow et al. summarise the types of practical LAM collaborations taking place. A 2008 IFLA report authored by Yarrow et al. examines findings from a survey of LAMs engaged in collaborative activity, identifying three specific types of collaboration occurring between LAMs: collaborative programming, collaborative electronic resources and joint-use/integrated facilities (2008). Yarrow et al. describe collaborative programming as a "joint cause", for example an exhibition that is often educationally or historically themed (2008: p.10). They note that the second type of collaboration, the creation of digital collections, is a key trend. In defining joint-use/integrated facilities, Yarrow et al. base the term 'joint-use' on the Online Dictionary for Library and Information Science (ODLIS) (see: http://www.library.ucsb.edu/research/db/1182) which defines the term as "a cooperative arrangement between a library and another institution, such as a school, community college, or university, in which both institutions share the same facility and/or collections" (Reitz, 2014). Yarrow et al. also cite Dornseif who in 2001 defined a continuum of integration. Unlike the Collaboration Continuum of Zorich et al., Dornseif's continuum categorises levels of collaboration found specifically in the context of physically integrated facilities 
and includes three levels of integration between institutions based on resources, operations and management. Minimal integration: "co-located facilities with individual services maintained", selective integration: "sharing of specific projects or departments" and full integration: "both facilities share one mission" (Yarrow et al., 2008: p.25) with integrated staff, materials, policies and procedures. Dornseif suggests that the level of integration between two facilities should depend on the needs of their users, however it is often the need for self governance that decides the extent of the integration: "these decisions are often driven by each library's need for autonomy" (Dornseif, 2001: p.107).

Despite these definitions of collaboration and convergence, Klimaszewski notes that the interchangeable use of the terms throughout the literature is problematic: "this lack of intentionality in term usage may be having undue influence over discussions about the nature and feasibility of collaboration and convergence because each outcome potentially has very different implications for LAM practitioners and their institutions" (2015: p.353)

\section{An International Perspective}

Duff et al. note that professional dialogue around convergence between LAMs 
has become more focused in recent years due to changes in governance and administration:

Discussions have become more continuous and focused, partly in response to the creation of new governmental mechanisms for funding and managing cultural heritage resources in a number of jurisdictions... and partly in response to administrative realignments within the sector which have merged previously separate institutions (Duff et al., 2013).

In England and Wales public libraries and museums were brought under the jurisdiction of local government under the 1964 Public Libraries and Museums Act; despite being governed by the same legislation a collaborative vision for libraries and museums was not published, "some form of collaboration was envisioned but cooperation specifically between libraries and museums was not spelt out in the Act" (Owen and Johnson, 1999: p.10). Since the creation of the 1964 Act, UK public libraries and museums have been affected by several changes to government structure, particularly since the year 2000 (Martin, 2007: p.82). The Museum, Libraries and Archives Council (MLA) was launched in 2000 and over a period of twelve years acted as a strategic lead "improving England's museums, libraries and archives; by providing the sector with 
strategic leadership, acting as an authoritative advocate and champion, advising stakeholders on best practice and assisting the Department for Culture Media and Sport with the delivery of specific initiatives" (Museum, Libraries and Archives Council, 2012: p.4).

In 2012, responsibility for supporting the development of libraries and museums was transferred to Arts Council England (ACE) after the Museum, Libraries and Archives Council was abolished by the government due to "a difficult financial climate" with the aim of bridging "some artificial divides... and get the maximum bang for the taxpayer's buck" (Department for Culture, Media and Sport, 2010). ACE continues to strategically lead the development of libraries and museums alongside the arts and remains a key provider of funding across these three sectors. Their relevant professional bodies, including the Chartered Institute of Library and Information Professionals (CILIP), the Society of Chief Librarians (SCL) and the Museums Association (MA), also support libraries and museums as each organisation aims to develop workforce skills and act as an advocate for their sector (Chartered Institute of Library and Information Professionals, 2016a; Society of Chief Librarians, 2016; Museums Association, 2016a). 
Recent consultations looking at the future of libraries stress, in the current environment, the significance of new ways of working - these include colocation with other council services, partnerships with other cultural heritage organisations, and agencies outside the sector. (Department for Culture, Digital, Media and Sport, 2016) and one of ACE's key strategic aims for museums 2015-2018, is to support them to form partnerships (Arts Council England, 2017).

Libraries in North America have been credited as prolific collaborators (Allen and Bishoff, 2001) with examples including the Colorado Digitisation program and the Houston Public Library and Houston Children's museum (Storey, 2003). Marcum (2014) has commented with regard to the US, that: 'IMLS grants have enabled libraries and museums to partner not only with each other but also with other kinds of cultural institutions' (p.77), and has outlined the drivers of this: 'The need to compete for public attention, the desire to save money, and the encouragement of government grants have all played a part in stimulating the rise in cultural agency collaborations' (p.78). She also acknowledges another key factor: 'LAMs are partnering in new ways because they now can. Digital technology has opened avenues to new kinds of service - and better ones' (p.78). 
A report on a recent summit on the value of libraries, archives and museums in a changing world, hosted by the Canadian Museums Association and Library and Archives Canada acknowledges that it has 'become apparent that to foster innovation and to meet the demands of today's clients, memory institutions can no longer go it alone. Partnership and collaboration, between memory institutions as well as with non-traditional partners, are keys to success. And, while 'Partnerships not only provide a means to attain our goals more efficiently', they also afford unexpected 'synergies' and 'serendipitous opportunities'. The financial drivers are also recognised: 'Competing for public funding with schools, hospitals, or key infrastructure projects requires memory institutions to show their worth on all fronts ...' (Libraries and Archives Canada 2017).

In recent years government interest in convergence has been most notable in Australia and New Zealand where cultural heritage institutions are termed locally as GLAMs. Both countries are at the centre of a wave of recent research into convergence (Davis and Howard, 2013; Wellington, 2013; Robinson, 2016; Howard et al., 2016) and several cross-sector initiatives. Examples of bureaucratic developments in the region include the formation of the Collections 
Council of Australia in 2004, based on the need for national coordination of the GLAM sectors (Birtley, 2006) and the 2006 Third Cultural Accord in New South Wales, Australia which provides funding for GLAM collaboration (Robinson, 2016: p.2). A well known example of convergence in Australia is the Albury LibraryMuseum in New South Wales, which aims to provide "seamless access" to library and museum collections (Robinson, 2012: p.416), and in New Zealand the Puke Ariki in New Plymouth is described as "a full prototype for convergence" (Robinson, 2012: p. 426), integrating library, museum and tourist information.

Despite a relatively high level of convergence in Australia, Davis and Howard argue that there is 'little explicit articulation of a 'true' GLAM vision' where multiinstitutional collaboration and convergence in terms of management and longterm projects would be the norm" (2013: p.20), and call for more investment in convergence, including the establishment of a Commonwealth government GLAM organisation to provide "strategic leadership for the cultural-heritage sector, enabling Australia to become a leading GLAM nation" (2013: p.18). A recent innovation study Challenges and Opportunities for Australia's Galleries, Libraries, Archives and Museums (Mansfield et al., 2014) found that although boundaries between Australian galleries, libraries, archives and museums are 
more porous than expected, more needs to be done to allow the these sectors to compete in the digital environment including strategic initiatives and a collaborative framework to "enable the sector to step decisively into the future" (Mansfield et al., 2014: p.viii).

Norway's ABM-utvikling is another example of a government merger bringing LAMs together under a unified bureaucratic organisation. Formed in 2003 ABMutvikling merged three organisations and aimed to promote core values shared across all three sectors, including democracy, the value of culture, access to information, diversity and social integration (Østby, 2006). Funded and governed by the Norwegian government, AMB-utvikling has announced the Norwegian digital library project; a plan to create a universal digital library experience that also includes archive and museum material (Hindal and Wyller, 2004).

The literature thus reflects that over the last two decades convergence, at varied levels, has emerged as a key theme in both the library and museum profession, including academic explorations of what constitutes convergence and how it is being put into practice. International developments, particularly in Australia, the USA and Canada, demonstrate a trend for cultural legislative 
frameworks that promote cross-sector collaboration, potentially driven by a need to make efficiency savings alongside recognition of the common ground shared by libraries, archives and museums. This common ground is explored in the next section.

\section{The Relationship between Libraries and Museums}

The lines between the LAMs are blurring as their similarities are emphasised more than their differences. This calls into question not just what LAMs are, and it also reveals our expectations about what we believe they should be in the twenty-first century

(Klimaszewski, 2015: p. 351)

Libraries and museums share missions, values and historic origins, however despite these commonalities each institution is viewed as a separate domain. This segregation is widely attributed to the rise of defined professional practices during the early twentieth century (Given and McTavish, 2010; Martin, 2007), which by the 1970s had created "distinct institutions" (VanderBerg, 2012: p. 139). Throughout the literature the subject of convergence between cultural 
institutions prompts many to scrutinise the shared role that libraries and museums play in society:

Libraries, archives, and museums are places where we learn about ourselves, the world around us, and what came before us. They inspire us to make a better future by helping us remember and understand the past (Dupont, 2007: p.13).

Several authors question whether convergence is a new phenomenon or merely a re-visiting of earlier joint library and museum models that later became out-dated by the rise of professionalism. (See Convergence or ReConvergence? and Professionalism and Divergence below.)

\section{Libraries and Museums as 'Memory Institutions'}

Due to their preservation of cultural heritage, libraries and museums are often referred to as 'memory institutions' alongside archives (Dempsey, 2000; Dupont, 2007; Tanackovic and Badurina, 2009). The term can be traced back to Hjerppe in 1994 who used the phrase in reference to "libraries, archives, 
museums, heritage institutions, and aquaria and arboreta, zoological and botanical gardens" (1994: p.1). Dempsey strongly argues the importance of 'memory institutions':

They organise the European cultural and intellectual record. Their collections contain the memory of peoples, communities, institutions and individuals, the scientific and cultural heritage, and the products throughout time of our imagination, craft and learning. They join us to our ancestors and are our legacy to future generations (Dempsey, 2000).

Mickalko recognises that 'memory institutions' have an impact on civilization over long periods of time, "Cultural institutions - which many of us by now have become comfortable in calling "memory institutions" - are a crucial bedrock component in the overall order of civilization" (2007: p.75). Mickalko goes on to argue that cultural history is invaluable and when lost is hugely damaging, "such a loss does not need to be explained. We just feel it” (2007: p.77). Trant highlights the popular bureaucratic use of 'memory institution': "the memory institution has captured the imagination of policy-makers as a powerful metaphor for the social role of libraries, archives and museums' (2009: p.369).

Despite wide acceptance and use of the term 'memory institution' to describe libraries, museums and archives, Robinson argues that although these 
institutions are united in gathering and preserving information, the use of 'memory institution' to describe all three domains over simplifies the concept of memory:

Their sweeping classification as 'memory institutions' in the public sector and the academy oversimplifies the concept of memory, and marginalises domain-specific approaches to the cataloguing, description, interpretation and deployment of collections that lead museums, libraries and archives to engage with history, meaning and memory in significantly different ways (Robinson, 2012: p.414).

Robinson instead calls for analytical discourse that "acknowledges nuance, diversity and polyphony in the representation of history and cultural memory" (2012: p.414). Although there is some disagreement over the suitability of the term 'memory institution' to describe libraries and museums, many throughout the literature are unanimous in recognising the missions and values shared by both domains.

It must, however, be remembered that libraries and museums are more than 'memory institutions'. 
Public libraries provide learning and information resources for individuals, families, businesses, and nonprofit organisations. In their role as community anchor institutions, they create opportunities for people of all ages through access to collections and technology. Public libraries support community improvement by providing programming that addresses the health, education, and workforce development needs of local residents. Libraries are places where people can gain assistance with research and information needs from knowledgeable library staff. In communities across the nation, local public libraries complement commercial development activity and provide attractive neighbourhood amenities in residential settings. (Swan et al, 2015: p.1)

This breadth of service and impact on the part of public libraries is reflected with regard to museums, too. The American Alliance of Museums, for example, highlights the 'community anchor' role played by museums through, for example, a range of programs tailored to different community groups including veterans and military families, social service related programs, adults with cognitive impairments, language classes, job training programs, work with teachers, school groups and researchers. It also notes the contribution their visitors make to the economy and tax revenues (American Alliance of Museums 
n.d., 2017). There are many similarities between libraries and museums in this respect.

\section{Shared Missions and Values}

Libraries, museums, and other cultural heritage institutions have superficial differences, but these superficial differences are far less significant than their real similarities in values, mission, and community impact. (Bell, 2003: p.58)

The missions and values shared by libraries and museums are widely discussed throughout the literature and are often viewed alongside the role of archives. Described broadly as "cultural heritage institutions working for the public good" (Allen and Bishoff 2002: p.43), key similarities between libraries and museums identified in the literature include access to information, cultural preservation, societal benefits and learning, "the fundamental roles of these three institutions in society are very similar; information, culture, education, leisure, and more recently, development of the local economy and democratic 
principles" (Tanackovic \& Badurina, 2009: p.229). Yarrow et al. state that public libraries and museums contribute to people's lives by providing "enjoyment and inspiration, cultural values, learning, economic prosperity and social equity" and argue that they contribute to "developing and sustaining cultural, social, educational and economic well-being" (2008: p.6).

Many authors emphasise the important role libraries, archives and museums play in preserving and making accessible cultural heritage, Pastore describes libraries and museums as trusted stewards of culture and heritage acting for the public good (2009) while Dupont argues that LAMs share a goal to "acquire, preserve, and make accessible artefacts and evidences of the world's social, intellectual, artistic, even spiritual achievements" (Dupont, 2007: p.13). By preserving and providing access to information libraries, archives and museums are credited with protecting democracy, allowing choice, enabling progress, promoting intellectual freedom, diversity, equality and developing an informed society (Gibson et al., 2007; Hindal and Wyller, 2004; Martin, 2007; Mickalko, 2007; Storey 2003). Pastore acknowledges libraries', archives' and museums' important role in communities as third places, "neither work nor home, the third place is a neutral community space, where people come together voluntarily 
and informally in ways that level social inequalities and promote community engagement and social connection" (2009: p.9).

Many highlight the educational purpose of libraries and museums and their role in lifelong learning (Bell, 2003; Gibson et al., 2007; Martin, 2007; Yarrow et al., 2008). Martin argues that libraries and museums are social agencies that provide many benefits through learning:

If we are truly to empower individuals to fulfilment, to enable them to maximize their human potential, to become contributing members of the knowledge economy, and to participate effectively in civic affairs, then we must build a fabric of social agencies that facilitates continuous lifelong learning". (Martin, 2007: p.88)

- Galleries Libraries - Archives - Museums

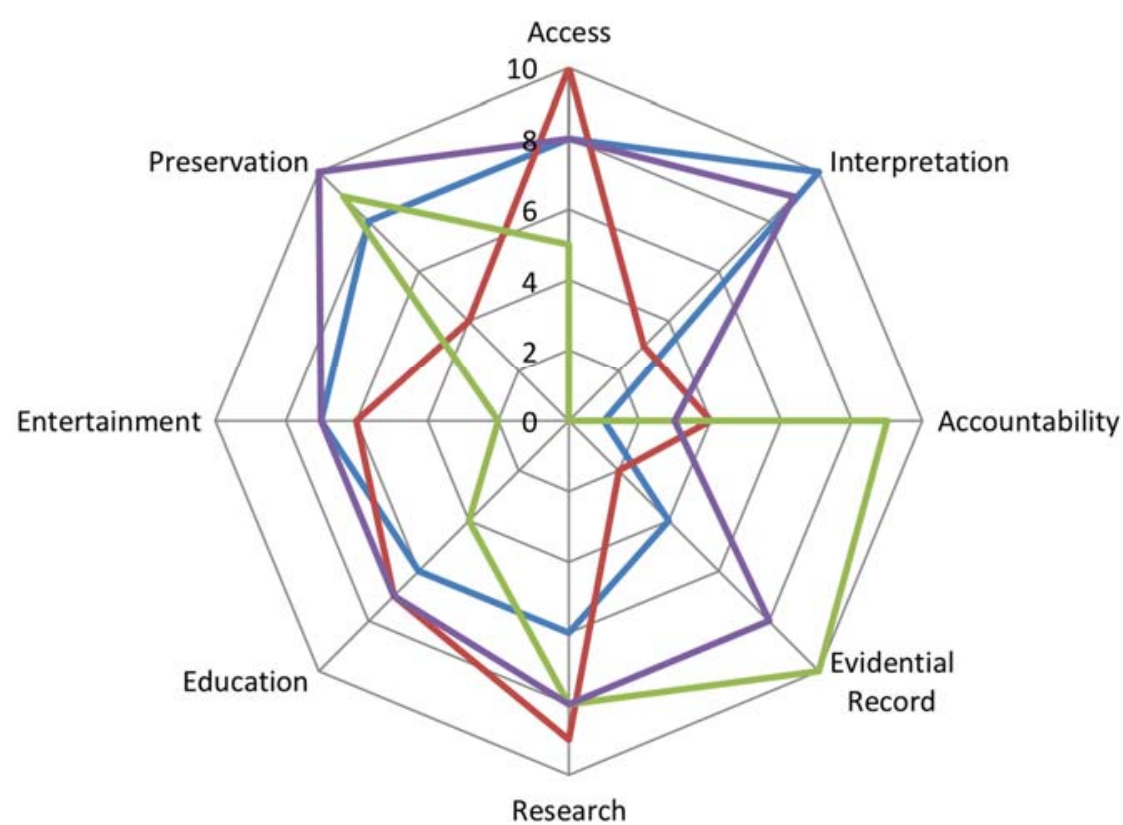


Figure 1 The GLAM Matrix (Wellington, 2013: p.307.) (Reproduced with author's permission.)

Wellington's 2013 GLAM Matrix ( figure 1), based on case study data, identifies eight core principles commonly shared by GLAMs. Each principle carries varying levels of relevance and importance for the four institutions, for example in the case of libraries and museums, both share access and research as core values but interpretation is more important for museums than it is for libraries (Wellington, 2013: p.307). Wellington's matrix provides a valuable insight into the similarities and differences in values between different types of cultural institutions including libraries and museums and aims to "contribute to our theoretical understanding of the sameness and difference between the GLAM entities" (Wellington, 2013: p.308).

\section{Convergence or Re-Convergence?}

Defining a future in which the end-goal is to obliterate the perceived differences of libraries, archives and museums seems to assume that 
these institutions have always been defined distinctively. History shows that this is not the case. (VanderBerg, 2012: p.138-139)

The merging of libraries and museums may be viewed by many as a novel approach to service delivery, however it has been argued that the phenomenon is not entirely new as "all libraries, archives and museums share a common institutional legacy" dating back to the Museon of Alexandria (Martin, 2007: p.81). It is also argued that Renaissance and Baroque thinkers considered all information objects as part of a single collection, "knowledge and objects of all kinds belonged together and formed one single intellectual space" (Kirchhoff, Schweibenz and Sieglerschmidt, 2009: p.252).

The history of western libraries, archives and museums is described as holistic (Waibel and Erway, 2009) and several authors compare contemporary convergence with the 'cabinets of curiosities' compiled from the sixteenth century onwards (Dilevko and Gottlieb, 2004; Marcum, 2014; Paulus, 2011) suggesting that digital technology allows a return to this collecting ethos "our computers are cabinets of curiosities" (Marcum, 2014: p.86). Others trace the differences between libraries and museums back to the invention of the printing press, which led to a distinction between books and objects (Martin, 2007). 
Given and McTavish argue that library, archive and museum convergence is rather a form of re-convergence, a return to goals that were shared during the Nineteenth Century:

During the nineteenth century, libraries, museums, and archives could overlap in terms of their political function and physical space.... elite patrons in England, the United States, and Canada regularly grouped these institutions together, arguing that they could both elevate and educate the "lower" classes while providing cities with visible signs of civilization. (Given and McTavish, 2010: p.8)

However the idea of re-convergence as an argument for the merging of libraries and museums is rejected by Cannon who argues that looking to the past for solutions to contemporary challenges is ironic:

Much of the pro-convergence literature is founded upon this central irony: we must embrace change to remain relevant in the 21 st century while simultaneously evoking outdated collecting practices of centuries past and therefore arrive at a 21 st century solution via 17 th century practices. In other words, convergence as Ouroboros. (Cannon, 2013: p.71) 
The growth of libraries, archives and museums throughout the nineteenth and twentieth centuries and their developing professional practices are cited throughout the literature as dividing cultural institutions - "the growth of libraries, archives, and museums made more evident their increasing separation" (Marcum, 2014: p.85). Marsden takes a cynical view that convergence is receiving an unfounded amount of attention and is merely part of an "everchanging institutional landscape in which we fight for money, attention, power even" (2001: p.22). This confrontational explanation of convergence suggests that a territorial mentality exists between library and museum professions that can be traced back to the development of defined professions.

\section{Professionalism and Divergence}

Towards the end of the nineteenth century separate professional bodies were formed, transforming amateur library and museum workers into professionals. The Carnegie Corporations played a great role, and their influence did not stop at libraries, and from the 1920s their remit extended to museum funding and 
promotion of professional skills within the museum workforce (Given and McTavish, 2010; Urban, 2014). The emergence of the museum profession allowed for ideological debate around the purpose of museums as their popularity grew alongside a need for community and learning programs. Meanwhile in the early 1900s, universities and colleges started to develop museum courses as more people became attracted to museum work (Teather, 1990). Library education had also developed; Melvin Dewey, described as "the person most responsible for establishing formal education for librarianship in the United States" (Miksa, 1986: p.359) opened the first library school in New York and by 1920 many of Dewey's graduates had gone on to teach library education in newly formed schools elsewhere (Miksa, 1986).

Several authors call for library and museum professions to work more closely with one another, calls that are largely motivated by the challenges faced by libraries and museums in the $21^{\text {st }}$ century. This is considered further in Professionalism and Divergence in Part 2.

\section{Motivations for Convergence}


Many authors throughout the literature highlight the complex and varied challenges that libraries, museums and other cultural institutions are facing in a volatile, changing environment. These challenges can be broadly categorised into the impact of digital technology and the effect it is having on user behaviour and economic, political and cultural change. Those who campaign for convergence argue that libraries and museums will stand a greater chance of surviving these challenges if they work together to overcome them.

\section{Digital Technology, Culture and Changing Users}

Digital technology is discussed as a major catalyst for change throughout the literature. User expectations are changing while the challenge of meeting these needs has been compounded by dwindling finances, as noted by Waibel and Erway, "this is a time of disruptive change and uncertainty for cultural repositories, which... are not only challenged to compete with commercial entities for the attention of their audiences online, but also by an economy in recession" (2009: p.324). Government information society policy that promotes universal digital access for all is cited as a key motivation for library and museum collaboration and convergence (Klimaszewski, 2015: p.358) and the digital world is viewed as responsible for dissolving the boundaries between 
their collections (Martin, 2003) as physical objects take on digital forms. It is also observed that convergence is less about cultural institutions coming together but instead about the merging of information types - "the convergence is text, audio, image, data, moving image ... That's the convergence" (Duff et al., 2013).

A reoccurring observation made throughout the literature is that the distinctions between libraries and museums has become artificial in a digital world where users have adapted to the capabilities of online single search engines and want information irrespective of where it comes from (Bishoff, 2004; Hedegarrd, 2003; Marcum, 2014; Martin, 2007; Østby, 2006; Tanackovic \& Badurina, 2009; Waibel and Erway, 2009). Waibel and Erway note that "while the collections of LAMs manage remain necessarily fragmented in the real world, potential users of these collections increasingly expect to experience the world of information as accessible from a single online search" (2009: p.2). Hedegaard argues "most of our users do not care where they find their information, whether it is in a book or a leaflet in the library, from a description of an artefact in the museum, or from an organisation's protocol in the archives, as long as they do find it" (2003: p.2) while Tanackovic and Badurina condemn the boundaries between cultural institutions as unbeneficial for users (2009). Martin puts similar emphasis on the 
needs and experience of the user by suggesting that all users want is "the stuff" regardless of where it comes from and warns that differing institutional procedures are likely to restrict access and mystify users (2007).

Australian findings suggest that user demographics are also changing:

The GLAM sector has relied heavily on older Australians as volunteers, loyal supporters and users of their services. The nature of support and engagement from younger Australians will be different and this will force the GLAM sector to respond with new methods of engagement. (Mansfield et al., 2014: p.9)

As a generation of digital natives emerges, libraries and museums are finding themselves competing for the attention of audiences who have heightened expectations of the services they receive:

How can library, archives and museum collections be made visible in a time where users have limited attention, institutions have limited budgets, but where offerings from the commercial world seem unlimited? How can cultural collections leverage the Googles, Amazons, flickrs and 
Facebooks dominating the networked environment? (Waibel and Erway, 2009: p.2)

Michalko refers to this competitive environment as "Amazoogle" world and notes that cultural institutions are failing to influence the digital information agenda: "we are not currently placing our collections into the global information flow of the Web in ways that people expect to discover them" (Michalko, 2007: p.79). This has challenged past assumptions that users naturally gravitate to cultural institutions for their information and leisure needs, instead institutions are having to reach out to their audience to prove their relevance (Yarrow et al., 2008). Marcum comments that the internet is more convenient for users than visiting a library while museums may be transplanted by entertainment accessed via digital devices, leading to a "fear of irrelevance" among libraries, archives and msueums (2014: p.78), a view shared by Michalko: "I genuinely think that as cultural institutions we are at a tipping point in terms of our relevance in the new information paradigm" (2007: p.77).

This, in the opinion of some, has resulted in a loss of institutional authority as the relationship between organisations and their audience changes, digital 
technology has allowed users to become creators as well as consumers of information - "what's happened in the world that we live in is that everyone has become both an expresser, as well as a consumer, of ideas" (Mansfield et al., 2014: p.20). Some propose that this needs to be embraced by encouraging users to collaborate with institutions via Web 2.0 technology (Kalfatovic et al., 2009), Yarrow et al. conclude that the user's experience of an institution is as important as the collections they hold (2008).

Although many in the literature argue that the interactions users now expect from libraries and museums is increasingly informed by their digital experiences, expecting information to be "immediately accessible, available and useable" (VanderBerg, 2012: p.136) and personalised to meet their individual needs (Mansfield et al., 2014), others have questioned the basis of the literature's assumptions relating to user needs. Cannon criticises the proconvergence literature for its lack of customer research: "it is time to ask our users whether or not the differences between libraries, archives, and museums matter to them or if they actually want converged institutions" (2013: p.86) and argues that although libraries, archives and museums must respond to users' needs, they must also "recognize the difference between reasonable needs and impossible desires" (2013: p.71). In reference to the converged Albury Library 
Museum in Australia, Wilson also questions whether libraries, archives and museums need to "go back to basics" in order to ask audiences whether or not they want converged institutions and asks whether users should be actively involved in implementing convergence: "there is the hoary question of how much participation our audiences have in the development and management of the facilities, because if you are talking about converging all elements of cultural facilities then isn't the audience one of those elements?" (2007: p.27).

Klimaszewski highlights the current lack of understanding about the users of digital collections created by libraries, archives and museums, acknowledging "user impact evaluation represents a complex, expensive, and time-consuming undertaking for LAMs" (2015: p.363). Klimaszewski points out that this "limited evidential understanding of user behavior and information needs" (2015: p.363) is the basis on which pro-convergence funders and policy makers are drawing their conclusions.

Despite this much of the literature takes the view that users are not interested in the differences between libraries, archives and museums, and Marty calls upon each profession to bridge the increasing gap between customer expectations and the reality of their workplace situation: "the future of cultural heritage organisations in the information age depends on the information professional's 
ability to bridge that gap and meet needs internal and externally, especially when those needs are contradictory" (2014: p.618). However this is a challenging proposition at a time when institutions such as public libraries and museums are being called upon to innovate while also facing significant economic, political and cultural challenges.

\section{Economic and Political Challenges}

The UK public sector has been seriously affected by the 2008 recession, described as "the worst economic recession in living memory" (Bramah et al., 2009: p.ii). Since 2010 when the UK government announced a $£ 1.165 \mathrm{bn}$ reduction in local authority grants (Watt, 2010) reductions in funding have seen English local authorities lose 27 per cent of their spending power between 2010 and 2016 (Hastings et al., 2015: p.3). In November 2015 the autumn spending review confirmed that local government will continue to face significant cuts until 2019-2020, with the Department for Communities and Local Government being one of the worst effected departments (Kirk, 2015). Recent research has found that the worst cuts have been to non-statutory services including cultural services, which has impacted negatively on user satisfaction: 
Cuts to services such as culture, environment and planning have been particularly deep. There is limited scope to continue to do this and it seems likely that cuts planned for the second half of the austerity programme will place a heavy burden on statutory services. (Hastings et al., 2015: p.8)

The negative impact on libraries is reflected by the reported withdrawal of over 300 UK public libraries from local authority control since 2011 (Public Libraries News, 2015b). Research by CILIP found that "cuts to staffing, opening hours, stock and budgets continue to have a negative impact on the quality of services" (Chartered Institute of Library and Information Professionals, 2012: p.9) and have recently passed a resolution condemning the "amateurisation" of library services (Poole, 2015) which was followed by the launch of the CILIP 'My Library by Right' campaign which aims to hold the government to account over the "withdrawal of financial and political support for public libraries in England" and instead uphold libraries as statutory services (Chartered Institute of Library and Information Professionals, 2016b). 
Museums have also experienced an "unprecedented level of cuts to public funding" since 2010 and public museums are amongst the worst affected, "cuts to public funding have inflicted serious damage on the sector, affecting almost every area of museum work" (Museums Association, 2014: p.3). Service areas affected include opening hours, charges, collections, exhibitions, events and outreach work while the museum workforce has been considerably diminished (Museums Association, 2014). This has led to concerns about the future sustainability of public museums, "any additional drop in funding may push them past breaking point" (Museums Association, 2014: p.19) and a 2015 Museums Association survey found that almost one in five regional museums has "closed a part or branch of their museum to the public in the last year, or plans such a closure in the year to come", and one in ten were expecting to introduce entrance fees to counteract reductions in local authority funding while others were considering selling items of their collection to raise necessary funds (Brown, 2016). The cultural sector has also seen traditional sources of funding diminish, including a $29 \%$ cut to Arts Council England's investment funds since 2010 (Davey, 2014: p.19), causing a situation described as a "second recessionary wave" for the cultural sector (Arts Quarter, 2011: p.4). In addition to the known cuts to public spending discussed here, an additional level of uncertainty has been generated by the result of the UK referendum in June 
2016 to leave the European Union, with the effect on libraries, museums and other cultural institutions and services being widely speculated on since the result (Anstice, 2016; Museums Association, 2016b; Museums Association, 2017; Thorpe, 2016).

In addition to the benefit of attracting new audiences, Robinson concludes that convergence among Australian cultural organisations has been motivated by "practical and financial benefits" through economy of scale, including shared organisational structures and staffing (Robinson, 2016: p.141). Throughout the literature the financial challenges faced by libraries and museums are identified as a key driver for convergence and integration is identified as an opportunity to make savings (Marcum, 2014; Brown and Pollack, 2000; Duff et al., 2013).

Yarrow et al. argue that pooling resources and breaking down physical barriers through collaboration will help libraries, archives and museums confront shared obstacles (2008) described as an "economies of scale" strategy (Marcum, 2014: p.78).

\section{Summary}


In Part 1, through a comprehensive, international literature review, the historical and ongoing relationship between libraries and museums and the [re]emergence of convergence as an international trend in the twenty-fist century is considered. Part 1 has provided a brief introduction to the background and current, dynamic context in which public library and museum authorities operate and looked at what convergence and its development means in this context, and what it does not - including perspectives from around the world. To achieve this both current and older sources have been consulted. It reflects on this with regard to libraries and museums as 'memory institutions', along with their other roles, and the similarities and differences in their missions and values. Motivations for convergence, including physical convergence, are discussed within the current, challenging environment where political, economic and technological opportunities and threats, for example, are influencing developments. Part 2 considers obstacles to convergence and the factors that can lead to success. 


\section{References}

Allen N and Bishoff L (2001) Academic library/museum collaboration: I'm ok, you're ok. In: ACRL 10th national conference, Denver, CO, 15-18 March 2001.

Allen N and Bishoff L (2002) Collaborative digitization: libraries and museums working together. Advances in Librarianship 26: 43 - 81.

American Alliance of Museums (n.d.) (2017) Museum Facts. Available at: http://www.aam-us.org/about-museums/museum-facts (accessed 7 September 2017).

Anstice I (2016) So, what does the referendum result mean for public libraries. In: Public Libraries News. Available at:

http://www.publiclibrariesnews.com/2016/06/11190.html (accessed 3 September 2016).

Arts Council England (2017) Supporting Museums. Available at: http://www.artscouncil.org.uk/supporting-art-and-culture/supporting-museums (accessed 27 October 2017). 
Arts Quarter (2011) Impacts of the recession on the UK cultural sector: findings from the 4th Arts Quarter survey. Report, Arts Quarter LLP, London, November.

Babbidge A (2013) Successful governance in independent museums. Report, Association of Independent Museums, Ludlow.

Bell CJ (2003) Library-museum connections in community colleges. Community \& Junior College Libraries 11(4): $45-68$.

Birtley M (2006) The Collections Council of Australia. Paper for the 2006 Australian State of the Environment Committee, Department of the Environment and Heritage, Canberra.

Bishoff L (2004) The collaboration imperative. Library Journal 129(1): 34-35.

Bramah M, Carroll N, Mudd A and Wing M (2009) Speaking up for public services: the vital role of the public sector in and beyond the recession. Report, Trades Union Congress Touchstone Pamphlet 7, London. 
Brown K and Pollack M (2000) Illinois libraries and museums:

connecting and collaborating for the future. Illinois Libraries 82(3): 209-215.

Brown M (2016) One in five regional museums at least part closed in 2015 , says report. Available at: https://www.theguardian.com/culture/2016/jan/13/onein-five-regional-museums-at-least-part-closed-in-2015-says-report (accessed 19 September 2016).

Cannon B (2013) The Canadian disease: the ethics of library, archives, and museum convergence. Journal of Information Ethics 22(2): 66-89.

Chaffin Hunter N, Lekk K and Oehlerts B (2010) Two librarians, an archivist, and 13,000 images: collaborating to build a digital collection. Library Quarterly 80(1): 81-103.

Chartered Institute of Library and Information Professionals (2012) A changing landscape: a survey of public library authorities in England, Wales and Northern Ireland 2012-13 summary report. Report, CILIP, UK, December. 
Chartered Institute of Library and Information Professionals (2016a) Our goal. Available at: http://www.cilip.org.uk/about/our-goal (accessed 16 October 2016).

Chartered Institute of Library and Information Professionals (2016b) My library by right. Available at: http://www.cilip.org.uk/advocacy-campaignsawards/advocacy-campaigns/support-your-library/my-library-right (accessed 29 October 2016).

Chartered Institute of Library and Information Professionals (2017) Public libraries statistics. Available at: https://www.cilip.org.uk/research/sectors/publiclibraries/public-libraries-statistics (accessed 7 September 2017).

Davey A (2014) Arts Council England grant-in-aid and lottery distribution annual report and accounts 2013/14. Report, Arts Council England. Report no. 12031401, 10 July. UK: The Stationery Office Limited.

Davis W and Howard K (2013) Cultural policy and Australia's national cultural heritage: issues and challenges in the GLAM landscape. The Australian Library Journal 62(1): 15-26. 
Dempsey L (2000) Scientific, industrial, and cultural heritage: A shared approach. In: Ariadne. Available at: http://www.ariadne.ac.uk/issue22/dempsey/ (accessed 29 January 2017).

Department for Culture Media and Sport (2010) Future of the Museums, Libraries and Archives Council. Available at: https://www.gov.uk/government/news/future-of-the-museums-libraries-andarchives-council (accessed 29 October 2017).

Department for Culture, Digital, Media and Sport (2016). Consultation outcome. Libraries deliver: ambition for public libraries in England 2016-2021 consultation draft. Available at:

https://www.gov.uk/government/consultations/libraries-deliver-ambition-forpublic-libraries-in-england-2016-2021/libraries-deliver-ambition-for-publiclibraries-in-england-2016-2021 (accessed 27 October 2017).

Diamant-Cohen B and Sherman D (2003). Hand in hand: museums and libraries working together. Public Libraries 42(2): 102-105. 
Dilevko J and Gottlieb L (2004) The evolution of library and museum partnerships: historical antecedents, contemporary manifestations, and future directions. Westport CT, London: Libraries Unlimited.

Dornseif KA (2001) Joint-use libraries. Resource Sharing \& Information Networks 15(1-2): 103-115.

Duff W, Carter J, Cherry JM, MacNeil H and Howarth LC (2013) From coexistence to convergence: studying partnerships and collaboration among libraries, archives and museums. Information Research 18(3).

Dupont C (2007) Libraries, archives, and museums in the twenty-first century: intersecting missions, converging futures. RBM: a journal of rare books, manuscripts, and cultural heritage 8(1): 13-19.

Evans M (2002) In: Web Wise Conference, Johns Hopkins University, March 2002. 
Gibson H, Cleeve M and Morris A (2007) Links between libraries and museums: investigating museum-library collaboration in England and the USA. Libri: International Journal of Libraries \& Information Services 57(2): 53-64.

Given L and McTavish L (2010) What's old is new again: the reconvergence of libraries, archives, and museums in the digital age. The Library Quarterly 80(1): $7-32$.

GOV.UK (2013) Policy: Library Services. GOV.UK. Available at: https://www.gov.uk/government/policies/library-services

Groninger, KR (2016) Introduction to museums and museum accountability in the United Kingdom. The Museum Review 1(1). Available at: https://themuseumreview.atavist.com/vol1no1groninger (accessed 7 September 2017).

Hastings A, Bailey N, Bramley G, Gannon M and Watkins D (2015) The cost of the cuts: the impact on local government and poorer communities. Report, Joseph Rowntree Foundation, York, March. 
Hedegaard R (2003) Benefits of archives, libraries and museums working together. In: 69th IFLA General Conference and Council, Berlin, Germany, 1-9 August 2003.

Hindal S and Wyller EH (2004) The Norwegian Archive, Library and Museum Authority: our role in a society based on knowledge and culture. Library Review 53(4): 207-212.

Hjerppe R (1994) A framework for the description of generalised documents. In: ISKO 1994 Conference, Copenhagen, Denmark, 21-24 June 1994.

Howard K, Hughes, HE, Oliver G and Partridge HL (2016) Passion trumps pay: A study of the future skills requirements of information professionals in galleries, libraries, archives and museums in Australia. Information Research 21(2).

Ilovelibraries (2017) What libraries do. Available at: http://www.ilovelibraries.org/what-libraries-do/about-americas-libraries\#public (accessed 7 September 2017).

Jones M (1997) Archives and museums: threat or opportunity? Journal of the Society of Archivists 18(1): 27-35. 
Kalfatovic M, Edson, M, Kapsalis E, Spiess K and Van Camp A (2009)

Smithsonian Team Flickr: a library, archives, and museums collaboration in web 2.0 space. Arch Sci 8: 267-277.

Kirchhoff T, Schweibenz W and Sieglerschmidt (2009) Archives, libraries, museums and the spell of ubiquitous knowledge. Archival Science 8: 251-266.

Kirk A (2015) Autumn statement 2015: How will government departments fare under George Osborne? Available at:

http://www.telegraph.co.uk/finance/autumn-statement/12007175/AutumnStatement-2015-How-will-government-departments-fare-under-GeorgeOsborne.html (accessed 24 October 2016).

Klimaszewski C (2015) Lumping (and splitting) LAMs: The story of grouping libraries, archives, and museums. Canadian Journal of Information and Library Science 39(3): 350-367.

Libraries and Archives Canada (2017) Final report: summit on the value of libraries, archives and museums in a changing world. Available from: 
https://www.bac-lac.gc.ca/eng/about-us/events/Pages/2017/final-report-summitvalue-libraries.aspx (accessed 10 September 2017).

Lindqvist K (2012) Museum finances: challenges beyond economic crises. Museum Management and Curatorship 27(1): 1-15.

Loach K, Rowley J and Griffiths J (2016) Cultural sustainability as a strategy for the survival of museums and libraries. International Journal of Cultural Policy 23(2):186-198.

Mansfield T, Brown T, Dockerty A, Griffith C and Winter C (2014) Innovation Study: Challenges and Opportunities for Australia's Galleries, Libraries, Archives and Museums. Report, Australian Centre for Broadband Innovation, CSIRO and Smart Services Co-operative Research Centre, Australia, August.

Marcum D (2014) Archives, libraries, museums: coming back together? Information \& Culture: A Journal of History 49(1): 74-89.

Marsden C (2001) Sectors and domains: some reflections on co-operation and integration. Journal of the Society of Archivists 22(1): 17-23. 
Martin RS (2003) Cooperation and change: archives, libraries and museums in the United States. In: World Library and Information Congress: 69th IFLA General Conference and Council, Berlin, 1-9 August 2003.

Martin RS (2007) Intersecting missions, converging practice. RBM: a journal of rare books, manuscripts, and cultural heritage 8(1): 80-88.

Marty PF (2014) Digital Convergence and the Information Profession in Cultural Heritage Organizations: Reconciling Internal and External Demands. Library Trends 62(3): 613-627.

McCall V (2016) Exploring the gap between museum policy and practice: a comparative analysis of Scottish, English and Welsh local authority museum services. Museum and Society 14(1): 98-115.

Michalko J (2007) Libraries, archives, and museums: achieving scale and relevance in the digital age. RBM: a journal of rare books, manuscripts, and cultural heritage 8(1): 75-79. 
Miksa F.L (1986) Melvil Dewey: the professional educator and his heirs. Library Trends 34(3): 359-381.

Museums Association (2014) Cuts survey 2014. Report, Museums Association, London, November.

Museums Association (2016a) About. Available at:

http://www.museumsassociation.org/about (accessed 24 November 2016).

Museums Association (2016b) What are the implications of Brexit for museums? Available at: http://www.museumsassociation.org/news/29062016brexit-briefing-museums-association (accessed 15 October 2016).

Museums Association (2017) Museums in the UK: 2017 report. Report: April 2017,London: Museums Association.

Museum, Libraries and Archives Council (2012) The Museums, Libraries and Archives Council (a company limited by guarantee) annual report and financial statements for the year ended 31 March 2012. Report for Parliament. Report no. ID 2493691, 5 July, UK: The Stationery Office Limited. 
Østby J.B (2006) Cross-sectorial challenges for archives, libraries and museums. IFLA Journal 32(3): 232-236.

Owen T and Johnson R (1999) Libraries, museums and archives collaboration in the United Kingdom and Europe. Art Libraries Journal 24(4): 10-13.

Paroissien L (2006) Museum governance and funding: international issues requiring local analysis and informed solutions. Conference paper: November, Taipei: Intercom. Available from: http://www.intercom.museum/documents/43Paroissien.pdf (accessed 7 September 2017).

Pastore E (2009) The Future of Museums and Libraries: A Discussion Guide. Report, Institute of Museum and Library Services. Washington, D.C., June.

Paulus M. J (2011) The converging histories and futures of libraries, archives, and museums as seen through the case of the curious collector Myron Eells. Libraries \& the Cultural Record 46: 185-205. 
Poole N (2015) Amateurisation' resolution, what's next? In: CILIP blog. Available at: http://www.cilip.org.uk/blog/amateurisation-resolution-what-s-next (accessed 22 October 2016).

Public Libraries News (2015a) What's Happening in Your Library? Public Libraries News. Available at: http://www.publiclibrariesnews.com/ (accessed 23 April 2015).

Public Libraries News (2015b) List of withdrawn libraries. Available at: http://www.publiclibrariesnews.com/about-public-libraries-news/news-topics (accessed 12 October 2016).

Reitz JM (2014) Joint use. ODLIS — Online Dictionary for Library and Information Science. Westport, Conn: Libraries Unlimited.

Robinson H (2012) Remembering things differently: museums, libraries and archives as memory institutions and the implications for convergence. Museum Management and Curatorship 27(4): 413-429. 
Robinson H (2016) A lot of people going that extra mile: professional collaboration and cross-disciplinarity in converged collecting institutions. Museum Management and Curatorship 31(2): 141-158.

Society of Chief Librarians (2016) About SCL. Available at: http://goscl.com/about/ (accessed 14 November 2016).

Soehner K (2005) Out of the ring and into the future: the power of collaboration. In: RLG Members Forum, Libraries, Archives and Museums Three Ring Circus, One Big Show?, St Paul, USA, 14 July.

Storey T (2003) Libraries: their role and relationships to other cultural institutions. OCLS Newsletter, April.

Swan D W, Grimes J, Owens T, Miller K, Arroyo J, Craig T, Dorinski S, Freeman M, Isaac N, O'Shea P, Padgett R, and Schilling P (2015) Public Libraries in the United States Survey: Fiscal Year 2012. Report no. IMLS-2015PLS-01, December, Washington, DC: Institute of Museum and Library Services. 
Tanackovic S.F and Badurina B (2009) Collaboration of Croatian cultural heritage institutions: experiences from museums. Museum Management and Curatorship 24(4): 299-321.

Teather, J.L (1990) Professionalization and the Museum. In: Schapiro M.S (ed) The Museum: A Reference Guide. Greenwood, N.J.: Greenwood Press, p.299.

Thorpe V (2016) After Brexit will the loss of EU funds pose a threat to UK arts? The Observer, 10 July.

Trant J (2009) Emerging convergence: thoughts on museums, archives, libraries, and professional training. Museum Management and Curatorship 24(4): 369-387.

Urban R.J (2014) Library influence on Museum information work. Library Trends 62(3): 596-612.

VanderBerg R (2012) Converging libraries, archives and museums: overcoming distinctions, but for what gain. Archives and manuscripts 40(3): 136-146. 
Waibel G and Erway R (2009) Think Global, Act Locally: library, archive and museum collaboration. Museum Management and Curatorship 24(4): 323-335.

Watt N (2010) George Osborne unveils £6.25bn spending cuts. The Guardian, 24 May.

Wellington S (2013) Building GLAMour: converging practice between gallery, library, archive and museum entities in New Zealand memory institutions. PhD Thesis, Victoria University of Wellington, New Zealand.

Wilson K (2007) It's a library, it's a museum. ArtReach, Autumn.

Yarrow A, Clubb B and Draper J.L (2008) Public libraries, archives and museums: trends in collaboration and cooperation. Report, International Federation of Library Associations and Institutions, The Hague, Netherlands, June.

Zorich D, Erway R and Waibel G (2008) Beyond the silos of the LAMs: collaboration among libraries, archives and museums. Report, OCLC, Dublin, Ohio, September. 